\title{
Gambaran Faktor yang Mempengaruhi Kontrasepsi Suntikan Pada Akseptor KB Suntik
}

\author{
Bina Aquari \\ Akademi Kebidanan Budi Mulia Palembang
}

\section{Informasi Artikel :}

Diterima : 30 April 2020

Direvisi : 10 Mei 2020

Disetujui : 20 Mei 2020

*Korespondensi Penulis : binaplb2201@gmail.com

\section{A B S T R A K}

Pada saat ini Keluarga Berencana telah dikenal hampir diseluruh dunia. Di Negara maju seperti Amerika Serikat, Keluarga Berencana bukan lagi merupakan suatu program atau gagasan, tetapi telah merupakan falsafah hidup masyarakatnya. Sedangkan di Negara sedang berkembang Keluarga Berencana masih merupakan program yang pelaksanaannya harus ditingkatkan. Indonesia merupakan salah satu penyumbang pertambahan penduduk dunia terbesar sampai dengan Tahun 2050 bersama dengan India, Pakistan, Brazil dan Nigeria. Data Klinik/BP Anisa dari bulan Januari - Desember Tahun 2019 yang menggunakan Kontrasepsi sebanyak 949 orang. Akseptor kb suntik sebanyak 787 orang, akseptor kb pil 135 orang, akseptor kb implant 6 orang, akseptor kb kondom 16 orang, akseptor kb MOW (Metode Operatif Wanita) 5 orang (Data Klinik/BP Anisa, 2019). Tujuan Penelitian ini yaitu diketahui Gambaran Faktor Yang Mempengaruhi Kontrasepsi Suntikan pada Akseptor KB Suntik".di Klinik / BP Anisa Desa Mainan Kecamatan Sembawa Kabupaten Banyuasin. Penelitian ini bersifat deskriptif yaitu suatu metode penelitian yang dilakukan dengan tujuan utama untuk membuat gambaran atau deskripsi tentang suatu keadaan secara objektif dengan desain cross sectional untuk mengetahui Gambaran Faktor Yang Mempengaruhi Kontrasepsi Suntikan pada Akseptor KB Suntik".di Klinik/BP Anisa Kec. Sembawa Kab.Banyuasin Tahun 2020. Hasil Penelitian ini didapatkan responden yang menggunakan kontrasepsi suntikan DPMA lebih banyak dan responden dengan umur tua dan paritas tinggi lebih banyak menggunakan kontrasepsi suntikan dalam penelitian juga pengetahuan responden sudah baik. Kesimpulan dari penelitian ini Karakteristik akseptor KB suntik berdasarkan umur dan paritas dan pengetahuan ibu tidak memenuhi pola penggunaan kontrasepsi rasional dalam pemilihan alat kontrasepsi. Sebagian besar responden menggunakan jenis kontrasepsi suntik DMPA

Kata Kunci :Faktor yang mempengaruhi kontrasepsi suntikan

\begin{abstract}
At this time Family Planning has been known almost all over the world. In developed countries like the United States, Family Planning is no longer a program or idea, but it is a philosophy of life for its people. Whereas in developing countries Family Planning is still a program whose implementation must be improved. Indonesia is one of the biggest contributors to world population growth until 2050 along with India, Pakistan, Brazil and Nigeria. Anisa's BP / Clinical Data from January - December 2019 using 949 Contraception. As many as 787 injectable KB acceptors, 135 pill acceptors, 6 implant KB acceptors, 16 condom KB acceptors, 5 MOW KB acceptors (Female Operative Methods) (Clinical Data / BP Anisa, 2019). The purpose of this research is to know the description of the factors that influence injection contraception in injection family planning acceptors. "In Clinic /
\end{abstract}


BP Anisa Toy Village, Sembawa District, Banyuasin Regency. This research is descriptive in nature, which is a research method conducted with the main objective to make a picture or description of a situation objectively with a cross sectional design to find out the Factors Influencing the Contraception of Injections in Injection KB Acceptors ". In Clinic / BP Anisa Kec. Sembawa Kab. Banyuasin in 2020. The results of this study found that respondents who use DPMA injection more contraception and respondents with old age and high parity use injection contraception more in the study as well as respondents' knowledge is good. The conclusion of this research is the age and parity and knowledge of the mother does not meet the pattern of rational use of contraception in the selection of contraception. Most respondents use this type of DMPA injection contraception.

Keywords: Factors affecting injection contraception

\section{PENDAHULUAN}

Menurut WHO (World Health Organization) Keluarga Berencana adalah tindakan yang membantu individu atau pasangan suami istri untuk mendapatkan objektif tertentu, menghindari kelahiran yang tidak diinginkan,mendapatkan kelahiran yang diinginkan, mengatur interval di antara kehamilan dan menentukan jumlah anak dalam keluarga. ${ }^{1}$ Berdasarkan Fakta-fakta menunjukkan bahwa masih banyak pasangan usia subur yang belum terpenuhi jenis kontrasepsi yang sesuai dengan pilihannya secara rasional, baik sesuai dengan tujuan pengaturan kelahirannya atau kondisi fisik biologisnya. Masih banyak pengguna kontrasepsi yang kurang efektif dan efisien serta memiliki jangka penggunaan sesuai kebutuhannya, apakah tujuannya untuk menunda atau menjarangkan kelahiran atau tidak menginginkan anak lagi.

Hormon progesteron dan estrogen yang terkandung dalam kontrasepsi suntik menyebabkan berbagai efek samping sehingga pemakaian kontrasepsi suntik dianjurkan maksimal 2 tahun atau 8 kali suntikan setelah itu ganti metode kontrasepsi lain untuk memulihkan keseimbangan hormon yang ada dalam tubuh. ${ }^{2}$ banyak faktor yang mempengaruhi kontrasepsi suntikan, karena keterbatasan waktu, kemampuan, tenaga, dan biaya peneliti, maka peneliti membatasi hanya meneliti umur, paritas dan pengetahuan ibu sebagai (variabel independen) dan sebagai (variabel dependen) pemakaian alat kontrasepsi suntikan. ${ }^{2}$

Tujuan Penelitian ini yaitu diketahui Gambaran Faktor Yang Mempengaruhi Kontrasepsi Suntikan pada Akseptor KB Suntik".di Klinik / BP Anisa Desa Mainan Kecamatan Sembawa Kabupaten Banyuasin?

\section{METODE PENELITIAN}

Penelitian ini bersifat deskriptif yaitu suatu metode penelitian yang dilakukan dengan tujuan utama untuk membuat gambaran atau deskripsi tentang suatu keadaan secara objektif dengan desain cross sectional untuk mengetahui Gambaran Faktor Yang Mempengaruhi Kontrasepsi Suntikan pada Akseptor KB Suntik".di Klinik/BP Anisa Kecamatan Sembawa Kabupaten Banyuasin Tahun 2020

Penelitian ini dilaksanakan pada bulan Februari tahun 2020. Populasi dalam penelitian ini adalah keseluruhan akseptor KB suntik di Klinik/Balai Pengobatan Anisa Tahun 2019. Berdasarkan rekam medik Klinik/Balai Pengobatan Anisa jumlah akseptor KB suntik adalah 787 orang. Sampel merupakan sebagian dari populasi yang diharapkan dapat mewakili populaisi, Sampel dari penelitian ini yaitu akseptor KB suntik yang berjumlah 89 orang. Menurut Hastono (2001), agar analisis penelitian menghasilkan informasi yang benar, paling tidak ada 4 tahapan dalam pengolahan data yang harus dilalui, yaitu: editing, coding, Entry Data, Cleaning data. Analisis data dalam penelitian ini yaitu analisis univariat, analisis yang di lakukan untuk melihat distribusi frekuensi dan persentase dari tiap-tiap variabel independen (umur, paritas dan pengetahuan) dan variabel dependen (pemakaian alat kontrasepsi suntikan). ${ }^{3}$

\section{HASIL PENELITIAN}
1. Variabel Penggunaan Alat Kontrasepsi Suntikan
Tabel 1 Distribusi Frekuensi dan Persentase Berdasarkan Kabupaten Banyuasin Tahun Penggunaan Alat Kontrasepsi Suntikan di Klinik /BP Anisa 2020 


\begin{tabular}{llcc}
\hline No & Kontrasepsi & n & Persentase \\
\hline 1 & Cyclofem & 31 & 34,8 \\
\hline 2 & DPMA & 58 & 65,2 \\
\hline & Jumlah & 89 & 100 \\
\hline
\end{tabular}

Dari tabel di atas dapat diketahui bahwa proporsi responden yang menggunakan kontrasepsi DPMA lebih banyak yaitu 58 $(65,2 \%)$.

\section{Variabel Umur}

\begin{tabular}{|c|c|c|c|c|}
\hline Tabel & 2 & $\begin{array}{l}\text { Distribusi } \\
\text { Persentase } \\
\text { Umur } \\
\text { Klinik/BP } \\
\text { Banyuasin } \\
\end{array}$ & $\begin{array}{r}\text { Frek } \\
\text { Respo } \\
\text { Anisa } \\
\text { Tahun } \\
\end{array}$ & $\begin{array}{l}\text { uensi dan } \\
\text { erdasarkan } \\
\text { den den di } \\
\text { Kabupaten } \\
2020\end{array}$ \\
\hline No & \multirow{2}{*}{\multicolumn{2}{|c|}{ Umur }} & $\mathrm{n}$ & Persentase \\
\hline 1 & & & 57 & 64,1 \\
\hline 2 & \multicolumn{2}{|l|}{ Muda } & 32 & 35,9 \\
\hline \multicolumn{3}{|c|}{ Jumlah } & 89 & 100 \\
\hline
\end{tabular}

Dari tabel diatas dapat dilihat bahwa distribusi responden usia tua yaitu ( $64,1 \%$ ) proporsinya lebih besar dari pada responden usia muda yaitu $32(35,9$ $\%)$.

\section{Variabel Paritas}

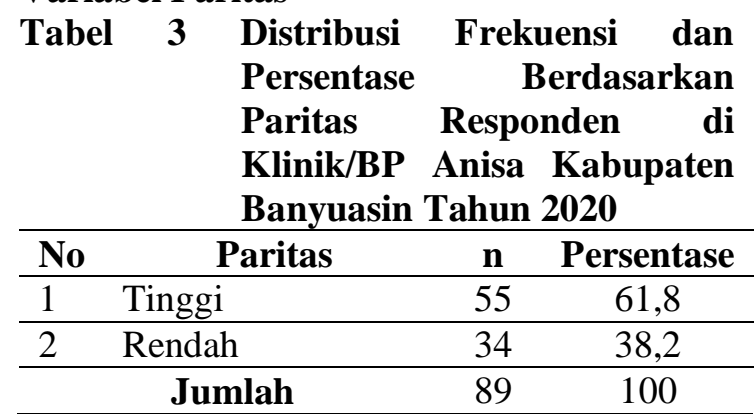

Dari tabel diatas dapat dilihat bahwa distribusi responden Paritas Tinggi yaitu $55(61,8 \%)$ proporsinya lebih besar dari pada responden Paritas Rendah yaitu 34 $(38,2 \%)$.

\section{Variabel Pengetahuan Ibu}

\begin{tabular}{ll} 
Tabel 4 & $\begin{array}{l}\text { Distribusi Frekuensi dan } \\
\text { Persentase } \\
\text { Berdasarkan } \\
\text { Pengetahuan Responden di } \\
\text { Klinik/BP Anisa Kabupaten } \\
\text { Banyuasin Tahun 2020 }\end{array}$ \\
\hline
\end{tabular}

\begin{tabular}{llcc}
\hline No & Pengetahuan & n & Persentase \\
\hline 1 & Baik & 56 & 62,9 \\
\hline 2 & Rendah & 33 & 37,1 \\
\hline & Jumlah & 89 & 100 \\
\hline
\end{tabular}

Dari tabel diatas dapat dilihat bahwa distribusi responden Pengetahuan Baik yaitu
$56(62,9 \%)$ proporsinya lebih besar dari pada responden Pengetahuan kurang yaitu 33 $(37,1 \%)$.

\section{PEMBAHASAN}

Berdasarkan hasil Analisis Univariat maka dapat di dapatkan variabel Umur, Paritas dan Pengetahuan Ibu dengan Penggunaan Alat Kontrasepsi Suntikan di Klinik/BP Anisa Kec. Sembawa Kabupaten Banyuasin Tahun 2020. yaitu Pemakaian kontrasepsi DPMA lebih banyak 65,2\% Menurut Manuaba (2002) depo provera untuk pertama kali di gunakan sebagai metode KB sejak tahun 1960 dan ternyata mendapat hasil yang memuaskan. Dan merupakan salah satu KB suntik yang paling banyak di gunakan. ${ }^{4}$ Sedangkan menurut Hartanto (2004) popularasi kontrasepsi suntik masih tinggi banyak wanita yang menerima kontrasepsi suntikan sebagai kontrasepsi yang memuaskan yang di sebabkan antara lain: Suntikan tidak ada hubungan saat senggama, Tidak perlu membeli atau menyimpan persediaan, Tidak di temukan efek samping minor seperti mual, atau efek samping yang lebih serius ${ }^{5}$ Dari hal yang di sebutkan searah dengan varney (2007), yang menyatakan DMPA merupakan alternatif yang sangat baik bagi wanita yang menginginkan kontrasepsi jangka panjang yang sangat efektif dan memiliki masalah kesehatan yang merupakan kontra indikasi metode kontrasepsi apapun yang mengandung estrogen. ${ }^{6}$

Variabel umur tua persentasinya lebih tinggi 64,1\% , Menurut teori Mochtar (2011) yang menyatakan bahwa ada hubungan yang bermakna antara umur dengan penggunaan kontrasepsi suntik karena pada usia 30-45 tahun wanita sudah tidak efektif dalam melahirkan anak karena pada usia tersebut wanita sangat bagus untuk mengakhiri kesuburannya. ${ }^{7}$

Paritas tinggi $61,8 \%$ presentasinya juga lebih tinggi yang menggunakan kontrasepsi suntikan, Menurut teori Mochtar (2011) yang menyatakan bahwa ada hubungan yang bermakna antara paritas dengan penggunaan kontrasepsi suntik karena jika paritas ibu tinggi wanita sudah tidak efektif dalam melahirkan anak. ${ }^{7}$

Pengetahuan ibu tentang kontrasepsi juga sudah cukup baik di buktikan dengan hasil presentasinya 62,9 \%. Penelitian ini sesuai dengan Henny (2009) di Desa Telaga sari Kecamatan Tanjung Morawa, adanya hubungan yang signifikan antara pengetahuan dan pengguna akseptor kontrasepsi suntik yang berkekuatan seadang. Hal ini berarti makin 
banyak pengetahuan ibu terhadap akseptor kontrasepsi suntik maka semakin baik pula pengetahuan ibu tentang kontrasepsi suntik. ${ }^{8}$ Menurut teori Notoadmodjo (2007) hal ini disebabkan oleh kurangnya informasi yang didapatkan oleh akseptor terhadap kontrasepsi suntik, meskipun akseptor memiliki pengetahuan yang cukup tentang kontrasepsi suntik namun tidak semua akseptor bersedia memakai kontrasepsi suntik. Dengan alasan mereka tidak mau melakukan kontrol ulang ${ }^{3}$ Hal ini, menunjukkan bahwa ada hubungan yang cukup kuat antara pengetahuan dengan pemilihan alat kontrasepsi suntik. Sejalan juga dengan penelitian teori Notoadmodjo (2007) hal ini disebabkan oleh kurangnya informasi yang didapatkan oleh akseptor terhadap kontrasepsi suntik, meskipun akseptor memiliki pengetahuan yang cukup tentang kontrasepsi suntik namun tidak semua akseptor bersedia memakai kontrasepsi suntik. ${ }^{3}$ Dengan alasan mereka tidak mau melakukan kontrol ulang. Hal ini, menunjukkan bahwa ada hubungan yang cukup kuat antara pengetahuan dengan pemilihan alat kontrasepsi suntik.

\section{KESIMPULAN}

Data hasil penelitian yang dilakukan di Klinik/BP Anisa Kecamatan Sembawa Kabupaten Banyuasin Tahun 2020 dapat di simpulkan bahwa: Karakteristik akseptor $\mathrm{K} B$ s u n t i k berdasarkan umur dan paritas dan pengetahuan ibu tidak memenuhi pola penggunaan kontrasepsi rasional dalam pemilihan alat kontrasepsi. Sebagian besar responden menggunakan jenis kontrasepsi suntik DMPA. Efek samping gangguan menstruasi, perubahan berat badan, pusing dan sakit kepala mayoritas dialami oleh pengguna suntik DMPA. Sedangkan, efek samping mual mayoritas dialami oleh pengguna suntik cyclofem.

\section{DAFTAR PUSTAKA}

1. Nurul \& Sri, Kesehatan Reproduksi dan Keluarga Berencana, Jakarta : penerbit Buku Kedokteran ECG ; 2018, Pendit, B., 2006, Ragam Metode Kontrasepsi, 32-35, Jakarta : ECG.

2. Pendit, B., 2006, Ragam Metode Kontrasepsi, 32-35, Jakarta : ECG.

3. Notoatmodjo, Soekidjo, 2010. Metodologi Penelitian Kesehatan, Jakarta, PT Rineka Cipta
4. Manuaba, Ida Bagus Ged. 2002. Ilmu Kebidanan Penyakit Kandungan dan Keluarga Berencana untuk Pendidikan Bidan, Jakarta. EGC

5. Hartanto, Hanafi. 2004, Keluarga Berencana dan Kontrasepsi, Pustaka Sinar Harapan, Jakarta.

6. Varney, Helen. 2007. Buku Ajar Asuhan Kebidanan Edisi 4. Jakarta : EGC.

7. Mochtar, Rustam. 2011. Sinopsis Obstetri Jilid 1. Jakarta : EGC.

8. Henny, 2009. Hubungan Antara Tingkat Pengetahuan dan Sikap Ibu PUS Akseptor Kontrasepsi Non Hormonal tentang Kontrasepsi Hormonal di telaga sari kecamatan tanjungmorawa. http://repository.usu.ac.id/bitstream/2356789/ 14253/1/0902377.pdf. diunduh 31 Januari $\underline{2020 .}$. 
